\title{
Effect of Water Stress on Maize Grown under Drip Irrigation System
}

\section{Rekaby, S.A. ; " ${ }^{1}$.A. Eissa ${ }^{2}$; S.A. Hegab ${ }^{1}$ and H.M. Ragheb ${ }^{2}$}

${ }^{1}$ Department of Soils and Water, Fac. of Agriculture, Al-Azhar University, Assiut, Egypt

${ }^{2}$ Department of Soils and Water, Fac. of Agriculture, Assiut University, Assiut, Egypt

*E.mail:mamdouhessa@Gmail.com

Received on: $7 / 11 / 2016$

Accepted for publication on: 12/12/2016

\section{Abstract}

This study aims to evaluate the effect of water stress on growth, nutrients uptake and yield of maize grown under drip irrigation. For this purpose field experiment in a randomized complete block design (RCBD) was carried out at the Agricultural Experimental Station farm of the Faculty of Agriculture, Assiut University, Egypt during the during the summer seasons of 2014 and 2015. Maize plants were irrigated by 100 or $75 \%$ of water requirements $\left(\mathrm{I}_{100}\right.$ and $\left.\mathrm{I}_{75}\right)$.

The obtained results of this study show that the irrigation of maize by $\mathrm{I}_{100}$ significantly $(P<0.05)$ increased the plant growth. Uptake of $\mathrm{N}, \mathrm{P}$, and $\mathrm{K}$ by maize irrigated by $\mathrm{I}_{100}$ increased by 11,7 and $16 \%$ in the first season and by 13 , 11 and $15 \%$ in the second season compared to that irrigated by $\mathrm{I}_{75}$. Increasing the irrigation level to $100 \%$ caused a 20 and $6 \%$ increase in the straw yield in the first and second season, respectively, also it caused a $20 \%$ increase in the biological yield in the first season compared to $\mathrm{I}_{75}$. The grain yield of maize irrigated by $\mathrm{I}_{75}$ was higher by 5 and $10 \%$ in the first and second season, respectively, compared to $\mathrm{I}_{100}$. Water use efficiency (WUE) was higher by 41 and $56 \%$ in the first and second season, respectively, in the case of $\mathrm{I}_{75}$ compared to $\mathrm{I}_{100}$. The data of the current study indicated that water stress caused a slightly reduction in the straw and biological yield of maize, on the other hand it caused a slightly increase in the grain yield.

From this study it recommended maize irrigated by $75 \%$ of water requirements was higher of grain yield than that received $100 \%$ of water requirements.

Keywords: Drip irrigation, Maize, Water stress, Nutrients uptake, Water Use Efficiency, Yield

\section{Introduction}

It is well know that the water resources in Egypt are limited to the share of Egypt in the flow of the Nile River by 55.5 billion $\mathrm{m}^{3}$. The deep groundwater in the deserts (mostly non-renewable) and a small amount of rainfall in the northern coastal area and Sinai. Meanwhile, water demand is continually increasing due to population growth, industrial development and the increase of living standards. Because of population growth, the per capita share of water has dropped dramatically to less than 1000 (about 700) $\mathrm{m}^{3} /$ capita, which, by international standards, is considered the "water poverty limit". The value may even decrease to $584 \mathrm{~m}^{3}$ /capita in the year 2025 (Abd El-Rahman, 2009). Water is the main limiting factor on yield production in the hot and dry summer period of semiarid regions. When water resources are a limiting factor in yield production, irrigation programs need to be applied to enable maximum production per unit of irrigation water. Deficit irrigation is one 
way of maximizing water use efficiency for higher yields per unit of irrigation water applied (Bekele and Tilahun, 2007). Water scarcity in the next decades is a real threat to food production especially in arid and semi-arid areas where water is the limiting factor in the expansion of cultivated land. Therefore, water management that maximize yield per unit of water consumed by plant is highly desired. In Egypt, limitation of water resources coupled with high population forced to a great competition for water supply that makes conservation and efficient use of water obligatory (Ibrahim, 1999; Gaber, 2000). This has stimulated the researchers to find new irrigation technologies, systems and irrigation strategies to improve water use efficiency. In modern irrigation systems, especially under arid or semi-arid conditions, water and nutrients are supplied simultaneously (fertigation). Under drip irrigation system water and nutrients have been used in highly efficient way.

Water stress (commonly known as drought) can be defined as the absence of adequate moisture necessary for normal plant grow and to complete the life cycle (Zhu, 2002). The lack of adequate moisture leading to water stress is common occurrence in rain fed areas, brought about by infrequent rains and poor irrigation (Wang et al., 2005). Water deficits affect every aspect of plant growth, including the anatomy, morphology, physiology and biochemistry. In maize, the reduction in grain yield caused by drought ranges from 10 to $76 \%$ depending on the severity of the drought and the growth stage at which it occurs (Bolaoos et al., 1993).

Maize is one of the most important cereal crops in the world. Moisture stress is an important factor affecting the growth of maize, especially in arid and semiarid regions (Eissa et al., 2013). Maize has been reported in the literature as having high irrigation requirements and sensitive to water stress (Rhoads and Bennett 1990; Stone et al., 2001). In arid and semi-arid regions, the daily evapotranspiration rates of maize often exceed $10 \mathrm{~mm} \mathrm{day}^{-1}$ for significant time periods (Howell et al., 1995). Maize are crops with high water requirements, have the ability to tolerate a short period of drought. However, water stress influences various physiological and biochemical processes. This may inhibit plant growth, decrease developmental activities of the cells and tissues and cause a variety of morphological, physiological and biochemical modifications. In contrast to other stress factors, drought stress does not occur abruptly, but develops slowly and increases with time in intensity and cause damages (Larcher, 2003). Drought affects water and nutrient supply to the plants thus affecting adversely plant development and yield (Jones and Qualset, 1984; Erdem et al. 2001). Water, being a universal solvent, is required for most of the metabolic activities of a plant and its shortage is expected to affect various physiological and biochemical processes in plants. Maize is one of the most important crops in the world and using drip irrigation in its production is commonly known. Irrigation and fertilization are crucial fac- 
tors for successful establishment of annual food crops such as cereal crops (Eissa et. al., 2013; Konopka et. al., 2009). Maize is a major cereal crop in Egypt due to its importance in human nutrition, animal and poultry where intervention in the industry dry feed rates of up to $70 \%$ and in the baking industry by $20 \%$, and also intervened in some industries such as extraction of glucose, fructose and oil.

The present research aims to determine the effect of water deficit treatments on: (1) the plant growth, (2) the N, P, and K uptake, (3) yield and yield components and (4) water use efficiency of maize in the semiarid conditions.

\section{Materials and Methods Field experiment}

The present investigation was carried out at the Agricultural Experimental Station farm of the Faculty of Agriculture, Assiut University, Egypt, which is located around the point of $27^{\circ} 12 \mathrm{~N}$ latitude and $31^{\circ}$ $09 \mathrm{E}$ longitude and at $51 \mathrm{~m}$ altitude. The soil was classified as TypicTorri Fluvents according to Soil Taxonomy (Soil Survey Staff, 2014). The main physical and chemical properties are summarized in Table 1. The experiment included two irrigation regimes $(100 \%$ of water requirements and $75 \%$ water requirements). The experimental design was randomized complete block design (RCBD) with three replicates. The experimental site was irrigated using a drip irrigation system. The in-line GR dripper laterals were installed $0.7 \mathrm{~m}$ apart. The emitters were spaced $0.30 \mathrm{~m}$ apart with a flow rate of $2.1 \mathrm{~L} \mathrm{~h}^{-1}$. Maize grains (Zea mays L., cv Single Hybrid 10) at rates of $24 \mathrm{~kg} \mathrm{ha}^{-1}$ were sown on the $14^{\text {th }}$ June, 2014 and the $13^{\text {th }}$ June, 2015 in the first and second season, respectively. Grains were sown on one side of the dripper's jet. Two grains were drilled in holes 3-4 $\mathrm{cm}$ deep and at $30 \mathrm{~cm}$ distance between plants spacing along the drip line and after 15 days the plants were thinned at one plant per each. The approximate plant population was 48000 plants per ha. All the agriculture practices were applied at the recommendations set by the Ministry of Agriculture and Land Reclamation (Egypt). $630 \mathrm{~kg}$ urea $(46 \% \mathrm{~N})$ per hectare was applied with the irrigation water at five equal doses applied weekly, started after 15 days of sowing, $149 \mathrm{~kg}$ of calcium super phosphate $\left(15.5 \% \mathrm{P}_{2} \mathrm{O}_{5}\right)$ per hectare was added directly to the soil in one dose before planting. Potassium fertilizer at a rate of $120 \mathrm{~kg}$ potassium sulphate $\left(48 \% \quad \mathrm{~K}_{2} \mathrm{O}\right)$ per hectare was added with the irrigation water in two equal does after 37 days and 50 days of planting to conserve it from teaching fertilizer rates. 
Table 1. The main physical and chemical soil properties $(0-30$ and $30-60 \mathrm{~cm}$ ) of the tested soil.

\begin{tabular}{|c|c|c|c|}
\hline Properties & Unit & $\begin{array}{c}\text { 0-30 } \\
\text { cm }\end{array}$ & $\begin{array}{c}30-60 \\
\mathrm{~cm}\end{array}$ \\
\hline particle size distribution Sand (\%) & $(\%)$ & 24.1 & 24.3 \\
\hline Silt (\%) & $(\%)$ & 62.4 & 62.5 \\
\hline Clay $(\%)$ & $(\%)$ & 13.5 & 13.2 \\
\hline Textural grade & - & $\begin{array}{l}\text { Silty } \\
\text { Loam }\end{array}$ & \begin{tabular}{|l} 
Silty \\
Loam
\end{tabular} \\
\hline Field capacity & $(\mathrm{v} \%)$ & 42.7 & 42.5 \\
\hline $\begin{array}{l}\text { Witling point } \\
\text { Bulk density }\end{array}$ & $\begin{array}{c}(\mathrm{v} \%) \\
\left(\mathrm{Mg} / \mathrm{m}^{3}\right)\end{array}$ & $\begin{array}{l}21.1 \\
1.29\end{array}$ & $\begin{array}{l}20.1 \\
1.30\end{array}$ \\
\hline $\mathrm{CaCO}_{3}$ & $(\%)$ & 5.42 & 5.08 \\
\hline $\mathrm{pH}(1: 2.5$ suspension $)$ & - & 7.54 & 7.78 \\
\hline EC (soil paste) & $\left.(\mathrm{dS} \mathrm{m})^{-1}\right)$ & 0.99 & 0.95 \\
\hline Organic matter & $\left(\mathrm{g} \mathrm{kg}^{-1}\right)$ & 2.41 & 2.25 \\
\hline Total nitrogen & $\left(\mathrm{mg} \mathrm{kg}^{-1}\right)$ & 560 & 520 \\
\hline Available nitrogen & $\left(\mathrm{mg} \mathrm{kg}^{-1}\right)$ & 67.2 & 62.4 \\
\hline Available Olsen P & $\left(\mathrm{mg} \mathrm{kg}^{-1}\right)$ & 11.78 & 11.32 \\
\hline Available-K & & 258.1 & 477.4 \\
\hline
\end{tabular}

\section{Calculation of irrigation water re- quirements}

The daily reference evapotranspiration $\left(\mathrm{ET}_{\mathrm{o}}\right)$ was estimated using Penman-Monteith's modified equation (Allen et al., 1998). The actual evapotranspiration $\left(\mathrm{ET}_{\mathrm{c}}\right)$ was calculated according the equation $\left(\mathrm{ET}_{\mathrm{c}}=\right.$ $\mathrm{ET}_{\mathrm{o}} \times \mathrm{K}_{\mathrm{c}}$ ). $\mathrm{K}_{\mathrm{c}}$ values used for maize were $0.60,0.83,1.20,0.90$ for growth stages initial, development, mid, and end, respectively (Allen et al., 1998). Based on the climate data in Table 2, the $\mathrm{ET}_{\mathrm{c}}$ values for maize were calculated. The estimated $\mathrm{ET}_{\mathrm{o}}$ was 698 and
$687 \mathrm{~mm}$ and the $\mathrm{ET}_{\mathrm{c}}$ was 645 and 634 $\mathrm{mm}$ in 2014 and 2015, respectively. The total irrigation water requirement during the whole growth season was 8344 and $8209 \mathrm{~m}^{3} \mathrm{ha}^{-1}$ in the first and second season, respectively (the application efficiency for drip irrigation $(\mathrm{Ea}=85 \%)$ and the leaching fraction was considered as $10 \%$ of water requirement). The irrigation treatments started after 20 days of transplanting. During the first 20 days (initial stage), the maize plants were irrigated according to the calculated irrigation requirements, while in other stages (development, mid, and end) the plants irrigated by 100 or $75 \%$ of water requirements. Water use efficiency (WUE) was calculated using the equation (WUE $=\mathrm{GY} / \mathrm{ET}_{\mathrm{c}}$ ), where GY equals grain yield, $\mathrm{ET}_{\mathrm{c}}$ equals seasonal actual evapotranspiration $(\mathrm{mm})$. Irrigation water use efficiency (IWUE) was estimated using the formula (IWUE = GY / IW), where IW equals seasonal crop water applied $(\mathrm{mm})$. The data in table 3 show the actual evapotranspiration, consumptive water use and irrigation water applied at different maize growth stages during the summer seasons of 2014 and 2015.

Table 2. Average monthly maximum $\left(T_{\max }\right)$ and minimum $\left(T_{\min }\right)$ temperature, relative humidity (RH), wind speed (WS) and reference evapotranspiration (ET ( $_{0}$ ) during 2014 and 2015 growing seasons.

\begin{tabular}{|c|c|c|c|c|c|}
\hline Month & $\mathbf{T}_{\max }$ & $\mathbf{T}_{\min }$ & RH (\%) & WS $\left(\mathrm{km} \mathrm{day}^{-1}\right)$ & $\mathrm{ET}_{\mathbf{0}}(\mathrm{mm})$ \\
\hline June,2014 & 37.8 & 22.3 & 33.2 & 148.8 & 7.54 \\
\hline July,2014 & 38.3 & 23.6 & 32.0 & 153.6 & 7.66 \\
\hline August,2014 & 38.4 & 23.9 & 33.8 & 172.8 & 7.67 \\
\hline September,2014 & 35.8 & 22.1 & 33.6 & 189.6 & 6.87 \\
\hline October,2014 & 31.3 & 16.9 & 36.7 & 117.6 & 4.44 \\
\hline June,2015 & 36.6 & 21.3 & 37.4 & 156.3 & 7.43 \\
\hline July,2015 & 38.8 & 22.8 & 35.9 & 98.4 & 6.74 \\
\hline August,2015 & 40.3 & 24.8 & 38.6 & 100.8 & 6.71 \\
\hline September,2015 & 38.5 & 23.8 & 38.5 & 175.2 & 6.93 \\
\hline October,2015 & 33.0 & 19.5 & 51.3 & 195.6 & 5.35 \\
\hline
\end{tabular}

Rainfall was 0 for the two growth season. Data were obtained from Assuit weather station ( Central Laboratory for Agricultural Climate). 
Calculation of water consumptive use (CU)

Actual evapotranspiration was estimated by the sampling method and calculated according to the following formula: Where:

$$
\text { C.U }=\left\{D \times B d \times\left(Q_{2}-Q_{1}\right) / 100\right\} / P
$$

C.U. = actual evapotranspiration (cm).

$\mathrm{D}=$ soil depth $(\mathrm{cm})$.

$\mathrm{Bd}=$ bulk density of soil $\left(\mathrm{Mg} / \mathrm{m}^{3}\right)$.

$\mathrm{P}=$ water density $\left(\mathrm{Mg} / \mathrm{m}^{3}\right)$.

$\mathrm{Q}_{2}=$ the percentage of soil moisture one day after irrigation (field capacity)

$\mathrm{Q}_{1}=$ the percentage of soil moisture before next irrigation.

Soil water content was monitored before and after each irrigation event starting 20 days after sowing at soil depth intervals of $0-30$ and 30$60 \mathrm{~cm}$. Soil samples were taken at positions immediately under the drippers by soil auger. The samples were weighted and then oven dried $\left(105^{\circ} \mathrm{C}\right)$. Percentage of soil moisture content at the tow depths was calculated on oven dry basis. The amount of water consumed in each irrigation treatment was obtained from the difference between soil moisture content before the following irrigation and one day after irrigation (field capacity).

\section{Collection of plant samples}

Composite plant samples, each consists of three plants, were taken from each experimental unit after 60 days of planting. Plant height and fresh weights were recorded. These samples were cleaned, washed with tap and distilled water, air dried, then dried in oven at $70{ }^{\circ} \mathrm{C}$ until constant weight, ground and stored for chemical analysis. Maize plants were harvested on October $7^{\text {th }}, 2014$ and October $8^{\text {th }}, 2015$ in first and second seasons respectively and the grain and total yield were recorded. Also, weights of ears, weight of grain per ear and seed index (100 seeds) were recorded grain and straw samples from each experimental unit were taken.

\section{Soil and plant analysis}

Composite soil sample was collected before cultivation from the ar (0- 30, 30- 60) cm. Air-dried, crushed, and sieved through a $2-\mathrm{mm}$ sieve. Then, the main physical and chemical properties of were determined according to Burt (2004). soil bulk density was determined using undisturbed soil samples of the different layers of the soil profile using cylinder method (Klute, 1986). The particle size distribution of soil samples was carried out according to the international pipette method (Klute, 1986). Soil $\mathrm{pH}$ was measured in $1: 2.5$ soil to water suspension using a digital $\mathrm{pH}$ meter. The electrical conductivity of the saturated soil paste $\left(\mathrm{EC}_{\mathrm{e}}\right)$ was estimated using the salt bridge method (Rhoades, 1982). Organic matter was determined wet oxidation method by (K2Cr2O $71 \mathrm{~N}$ and $\mathrm{H} 2 \mathrm{SO} 4$ conc.) and titrating with standardized $0.5 \mathrm{M} \quad$ [(NH4)2SO4.FeSO4.6H2O] according to (Jackson, 1973). Total calcium carbonate content was determined using a collins calcimeter. Available soil nitrogen was extracted by $2 \mathrm{M}$ potassium chloride, and then nitrogen in the extract was determined using micro-kjeldahl method Burt (2004). The soil available phosphorus was extracted using $0.5 \mathrm{M}$ so- 
dium bicarbonate solution at $\mathrm{pH} 8.5$ according to Olsen et al. (1954). The ratio of the soil to extract ant was 1:20and extract was filtered and measured calorimetrically using stannous chloride phosphomolybdicsulfuric acid system as describe by (Jackson, 1973). Available potassium was extracted by (ammonium acetate $1 \mathrm{M}$ at $\mathrm{pH} 7$ ratio $1: 10)$ method and measured by flame photometry(Jackson, 1973).

Plant samples were digested in $\mathrm{H}_{2} \mathrm{SO}_{4}$ and $\mathrm{H}_{2} \mathrm{O}_{2}$ as described by
Parkinson and Allen (1975) then were analyzed for $\mathrm{N}, \mathrm{P}$, and $\mathrm{K}$ as described by Page et al. (1982).

\section{Statistical analysis}

Data obtained in each season were statistically analyzed. Statistical computer program MSTAT-C, Crop $\&$ Soil Sciences Dept. Michigan State University was used. Mean values were compared for each other using Duncan's test at $P<0.05$. MSTAT (1987) micro computer program.

Table 3. Daily reference evapotranspiration $\left(\mathrm{ET}_{\mathbf{0}}\right)(\mathrm{mm})$, actual evapotranspiration $\left(\mathbf{E T}_{\mathrm{c}}\right)(\mathrm{mm})$, water consumptive use $(\mathrm{CU})(\mathrm{mm})$ and irrigation water applied (mm) at different maize growth stages during the summer seasons of 2014 and 2015

\begin{tabular}{|c|c|c|c|c|c|c|c|c|c|c|c|c|}
\hline & & & & Growtl & stage & & & & & & & \\
\hline & & Initial & I stage & $\begin{array}{r}\text { Devel } \\
\text { st }\end{array}$ & $\begin{array}{l}\text { pment } \\
\text { ge }\end{array}$ & $\begin{array}{r}\text { Mid-s } \\
\text { sta }\end{array}$ & $\begin{array}{l}\text { eason } \\
\text { ge }\end{array}$ & $\begin{array}{r}\text { Late- } \\
\text { st }\end{array}$ & $\begin{array}{l}\text { eason } \\
\text { ge }\end{array}$ & To & tal & \\
\hline & & $\begin{array}{c}14 \\
\text { June } \\
\text { to } \\
\text { 3 July } \\
\text { (20day) }\end{array}$ & \begin{tabular}{|c}
13 \\
June \\
to \\
2 July \\
(20day)
\end{tabular} & $\begin{array}{l}4 \text { July. } \\
\text { to } \\
\text { 2 Aug. } \\
\text { (30day) }\end{array}$ & $\begin{array}{c}\text { 3 July. } \\
\text { to } \\
1 \text { Aug. } \\
\text { (30day) }\end{array}$ & $\begin{array}{l}3 \text { Aug. to } \\
11 \text { Sept. } \\
\text { (40day) }\end{array}$ & $\begin{array}{c}2 \text { Aug. } \\
\text { to } \\
10 \\
\text { Sept. } \\
\text { (40day) }\end{array}$ & \begin{tabular}{|c|}
12 \\
Sept. \\
to \\
1 Oct. \\
(20day)
\end{tabular} & $\begin{array}{l}11 \text { Sept } \\
\text {.to } \\
\text { 30 Sept. } \\
\text { (20day) }\end{array}$ & $\begin{array}{c}14 \text { June. } \\
\text { to } \\
1 \text { Oct. } \\
\text { (110 day) }\end{array}$ & $\begin{array}{c}13 \text { June } \\
\text { to } \\
30 \text { Sept. } \\
\text { (110 day) }\end{array}$ & $\begin{array}{c}\text { Average } \\
\text { of the two } \\
\text { seasons }\end{array}$ \\
\hline & & 2014 & 2015 & 2014 & 2015 & 2014 & 2015 & 2014 & 2015 & 2014 & 2015 & \\
\hline $\mathbf{E T}_{0}($ & Im) & 137.50 & 137.10 & 199.30 & 200.50 & 257.90 & 257.90 & 103.05 & $91 . .44$ & 697.75 & 686.94 & 692.35 \\
\hline & $100 \%$ & 82.50 & 82.26 & 165.98 & 166.25 & 303.55 & 303.55 & 92.75 & 82.29 & 644.77 & 634.35 & 639.56 \\
\hline & $75 \%$ & 82.50 & 82.26 & 124.48 & 124.69 & 227.66 & 227.66 & 69.56 & 61.72 & 483.58 & 475.76 & 479.67 \\
\hline & $100 \%$ & $==$ & $===$ & 180.53 & 185.41 & 325.32 & 335.24 & 91.32 & 93.95 & 597.17 & 614.60 & 635.89 \\
\hline (C) & $75 \%$ & $===$ & $===$ & 139.30 & 143.43 & 235.51 & 240.12 & 70.23 & 65.41 & 445.04 & 448.96 & 447.0 \\
\hline Applied & $100 \%$ & 106.76 & 106.45 & 214.79 & 215.14 & 392.83 & 392.83 & 120.02 & 106.50 & 834.41 & 820.92 & 827.67 \\
\hline $\begin{array}{l}\text { water } \\
(\mathrm{mm})\end{array}$ & $75 \%$ & 106.76 & 106.45 & 161.09 & 161.36 & 294.62 & 294.62 & 90.02 & 79.87 & 625.18 & 615.69 & 620.44 \\
\hline
\end{tabular}

\section{Results and Discussion}

1. Effect of water stress on the growth of drip irrigated maize

The data in Fig. 1, 2, and 3 show the effect of the irrigation levels on the growth of 60 days-old maize. The irrigation of drip irrigated plants by $\mathrm{I}_{100}$ significantly $(P<0.05)$ increased the plant height and fresh and dry weights by 5,12 , and $3 \%$ in the first season and by 6,11 , and $8 \%$ in the second season compared to $\mathrm{I}_{75}$. It is clear that all the measured growth characters negatively affected by the lower water supply treatment as compared with the normal water supply treatment in both seasons. These results are in agreement with those ob- 
tained by Abd El-Hafez et al. (2001), Abdel Aziz and El-Bialy (2004), Galbiatti et al. (2004) and Omran (2005) who concluded that yield and its attributes of maize plants were gradually increased as a result of increasing in the availability of soil moisture content. The availability of water is an important factor in the growth of maize plants. Maize is one of the most efficient field crops in producing higher dry matter per unit quantity of water (Viswanatha et al., 2002; Megyes et al., 2005). Meleha (2006) reported that growth of maize is highly related to irrigation depth and it increases with increasing the irrigation level. These results are in harmony with those obtained by Abd El-Hafez et al. (2008), Abdel Maksoud et al. (2008) and Kara and Biber (2008).

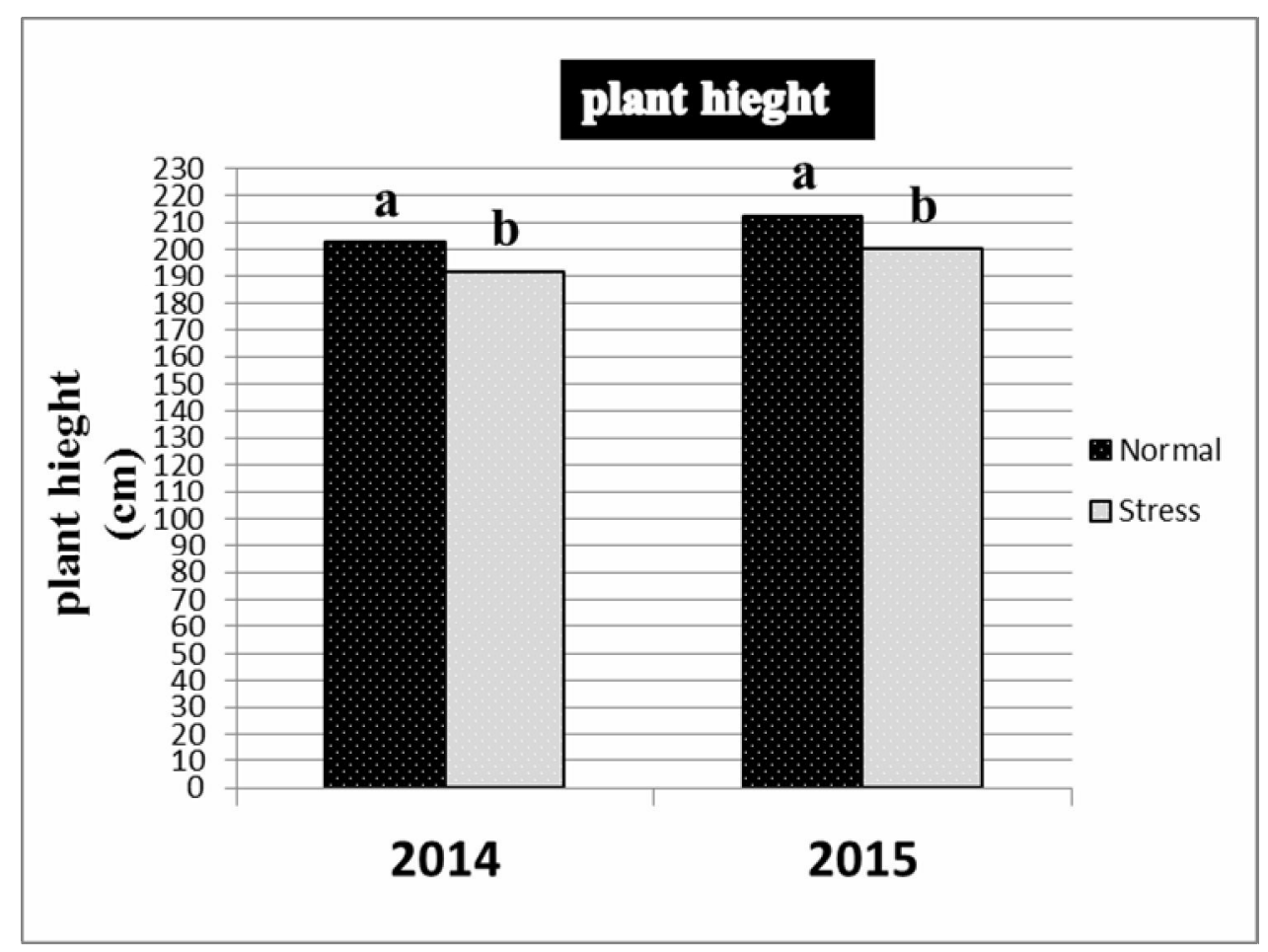

Fig. 1. Plant height of 60 days-old maize $(\mathrm{cm})$ as affected by irrigation rates 


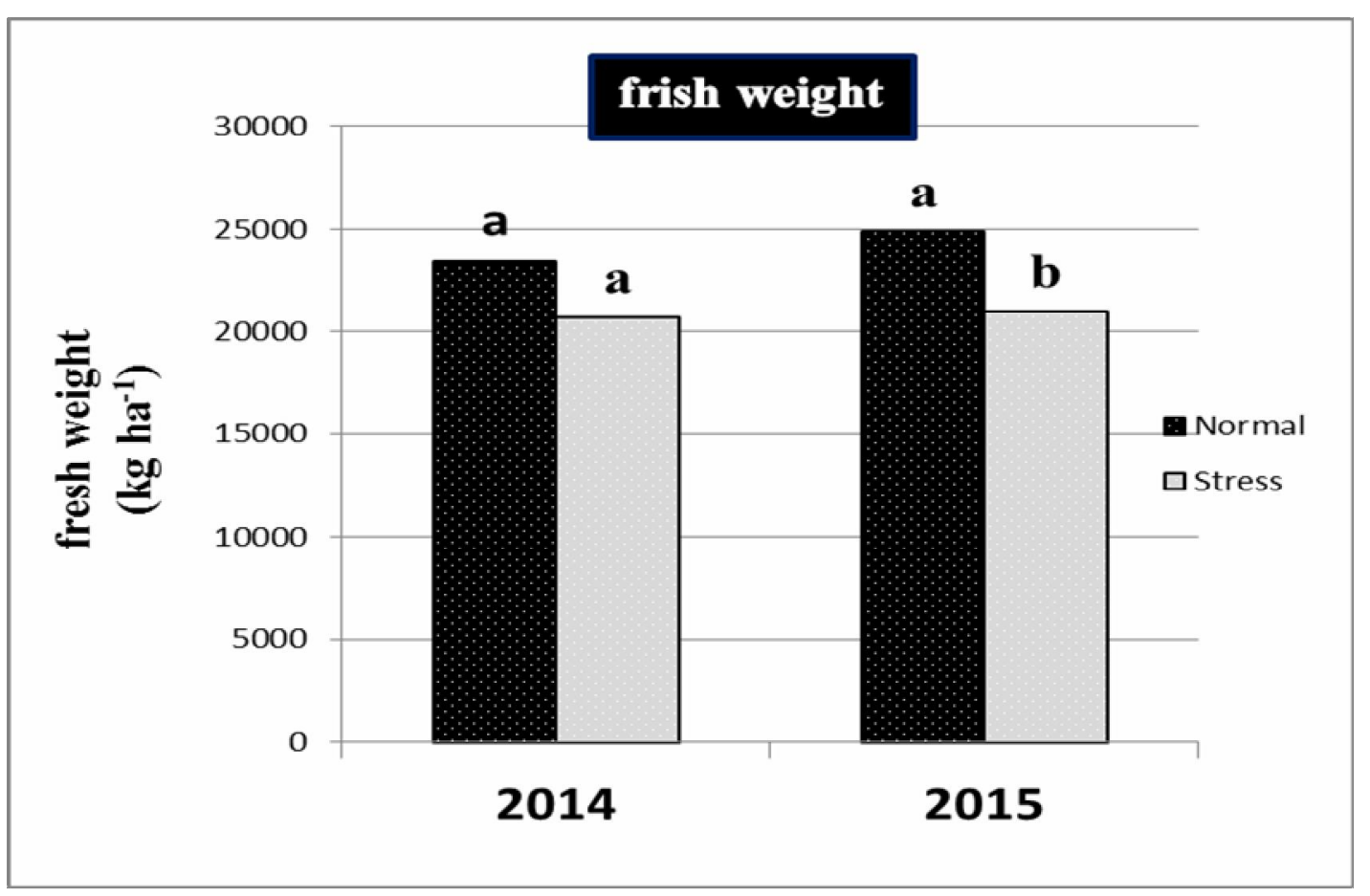

Fig. 2. Fresh weight ( $\mathrm{kg} / \mathrm{ha})$ of 60 days-old maize as affected by irrigation rate.

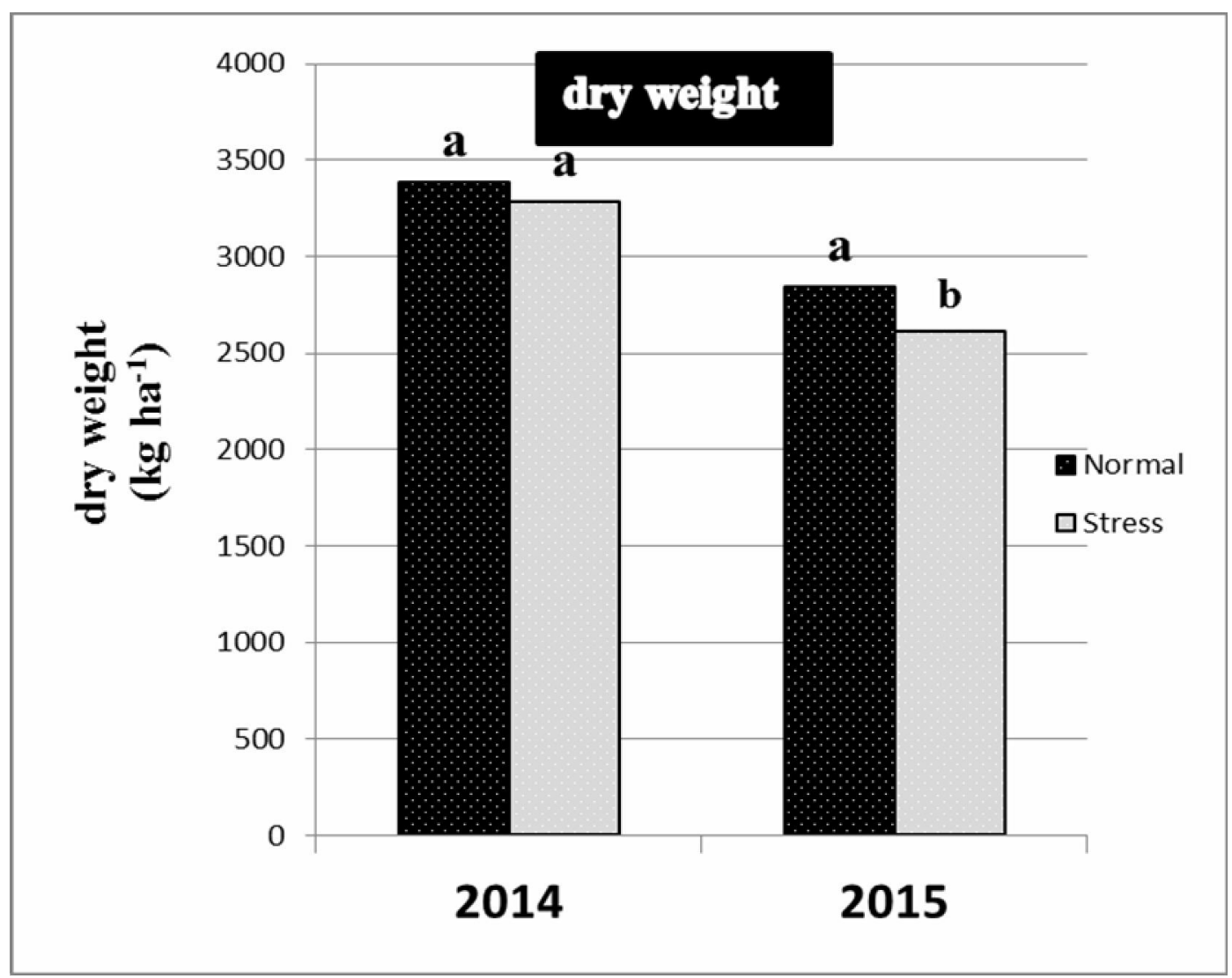

Fig. 3. Dry weight (kg/ ha) of 60 days-old maize as affected by irrigation rate. 
2. Effect of water stress on the $\mathbf{N}, \mathbf{P}$, and $K$ uptake by drip irrigated maize

Nitrogen $(\mathrm{N})$, phosphorus $(\mathrm{P})$, and potassium $(\mathrm{K})$ concentrations and uptake by 60 days-old maize affected significantly $(P<0.05)$ by the irrigation levels as shown in Table 4. Increasing the irrigation level to $100 \%$ of water requirement increased the uptake and concentrations of $\mathrm{N}, \mathrm{P}$, and $\mathrm{K}$ in the shoot tissues of 60 daysold maize. Nitrogen concentrations in the shoots of maize irrigated by $\mathrm{I}_{100}$ were higher by 22 and $4 \%$ than those irrigated by $\mathrm{I}_{75}$ in the first and second season, respectively. Phosphorus and potassium concentrations in the shoots of maize irrigated by $\mathrm{I}_{100}$ were higher by $16 \%$ than those irrigated by $\mathrm{I}_{75}$ in the first season. Uptake of $\mathrm{N}$, $\mathrm{P}$, and $\mathrm{K}$ by maize irrigated by $\mathrm{I}_{100}$ increased by 11,7 and $16 \%$ in the first season and by 13, 11 and $15 \%$ in the second season compared to that irrigated by $\mathrm{I}_{75}$. The current study clearly showed that water stress reduced the concentrations and uptake of $\mathrm{N}, \mathrm{P}$, and $\mathrm{K}$ by drip irrigated maize. From the previous results it could be mentioned that the increase of $\mathrm{N}, \mathrm{P}$ and $\mathrm{K} \%$ in maize plants may be attributed to increasing of soil moisture. As soil moisture content increased solubility and mobility of $\mathrm{N}, \mathrm{P}$ and $\mathrm{K}$ are increased (El-Nagar, 2003; Othman-Sanaa et al., 2005; Ibrahim and Kandil, 2007). Deficit irrigation had a negative effect on $\mathrm{N}$, $\mathrm{P}$, and $\mathrm{K}$ concentrations in the shoots of maize plants. As a result of vegetative growth reduction, the absorption of nutrient elements could be decreased (Pascale et al., 2001). Similar results were obtained by Silber et al. (2003).

Table 4. The concentrations $N$, $P$, and $K\left(\mathrm{~g} \mathrm{~kg}^{-1}\right)$ and uptake $\left(\mathrm{kg} \mathrm{ha}^{-1}\right)$ by 60 daysold maize as affected by the irrigation rates

\begin{tabular}{|c|c|c|c|c|c|c|c|c|c|c|c|c|}
\hline \multirow{3}{*}{ Irrigation level } & \multicolumn{6}{|c|}{2014} & \multicolumn{6}{|c|}{2015} \\
\hline & \multicolumn{2}{|c|}{$\mathbf{N}$} & \multicolumn{2}{|r|}{$\mathbf{P}$} & \multicolumn{2}{|c|}{$\mathbf{K}$} & \multicolumn{2}{|c|}{$\mathbf{N}$} & \multicolumn{2}{|r|}{$\mathbf{P}$} & \multicolumn{2}{|c|}{$\mathbf{K}$} \\
\hline & conc. & Uptake & conc. & Uptake & conc. & Uptake & conc. & Uptake & conc. & Uptake & conc. & Uptake \\
\hline$I_{100}$ & $25.30^{\mathrm{a}}$ & $86.16^{\mathrm{a}}$ & $5.58^{\mathrm{a}}$ & $18.13^{\mathrm{a}}$ & $22.97^{\mathrm{a}}$ & $75.99^{a}$ & $23.17 \mathrm{a}$ & $66.02^{\mathrm{a}}$ & $5.94^{\mathrm{a}}$ & $15.64^{\mathrm{a}}$ & $23.11^{\mathrm{a}}$ & $66.01^{\mathrm{a}}$ \\
\hline $\mathbf{I}_{75}$ & $20.80^{b}$ & $77.48^{b}$ & $5.15^{\mathrm{a}}$ & $17.01^{\mathrm{a}}$ & $18.93^{b}$ & $65.40^{b}$ & $22.33^{\mathrm{a}}$ & $58.48^{b}$ & $5.48^{\mathrm{a}}$ & $15.61^{\mathrm{a}}$ & $21.91^{\mathrm{a}}$ & $57.14^{b}$ \\
\hline
\end{tabular}

\section{Effect of water stress on ears weight, grains weight per ear, and seed index of drip irri- gated maize}

The data in Table 5 show the ears weight $(\mathrm{EW})$, grains weight per ear (GWE), and seed index (SI) of drip irrigated maize as affected by the irrigation treatments. In general the irrigation treatments have significant effects in the mentioned parameters. The low level of irrigation $\left(\mathrm{I}_{75}\right)$ caused a 9 and 5 increases in the ears weight $(\mathrm{EW})$, grains weight per ear
(GWE) in the first season and 7 and $10 \%$ in the second season compared to the high level of irrigation $\left(\mathrm{I}_{100}\right)$. Also the low level of irrigation $\left(\mathrm{I}_{75}\right)$ caused a 8 and $10 \%$ decrease in the seed index (SI) in the first and the second season compared to the high level of irrigation $\left(\mathrm{I}_{100}\right)$. The current study indicated that water stress increased the ears weight (EW) and grains weight per ear (GWE) of drip irrigated maize. Our results were in agreement with the results of Mansouri-far et al. (2010). They reported 
that when the amount of water decreased, the seed index was decreased. Also, Ogretir (1993) re- ported that the application of deficit irrigation on maize at the flowering period decreased the seed index.

Table 5. Ears weight (EW), grains weight (GWE) per ear, and seed index (SI) (gm.) of maize as affected by irrigation rates

\begin{tabular}{|c|c|c|c|c|c|c|}
\hline $\begin{array}{c}\text { Irrigation } \\
\text { level }\end{array}$ & \multicolumn{3}{|c|}{$\mathbf{2 0 1 4}$} & \multicolumn{3}{|c|}{$\mathbf{2 0 1 5}$} \\
\cline { 2 - 7 } & $\mathbf{E W}$ & $\mathbf{G W E}$ & SI & EW & GWE & SI \\
\hline $\mathbf{I}_{\mathbf{1 0 0}}$ & $106.86^{\mathrm{b}}$ & $85.14^{\mathrm{a}}$ & $28.77^{\mathrm{a}}$ & $104.87^{\mathrm{b}}$ & $72.00^{\mathrm{b}}$ & $27.97^{\mathrm{a}}$ \\
\hline $\mathbf{I}_{\mathbf{7 5}}$ & $116.15^{\mathrm{a}}$ & $89.48^{\mathrm{a}}$ & $26.27^{\mathrm{b}}$ & $112.42^{\mathrm{a}}$ & $79.46^{\mathrm{a}}$ & $25.23^{\mathrm{b}}$ \\
\hline
\end{tabular}

Means denoted by the same letter indicate no significant difference according to Duncan's test at $P<0.05$

4. Effect of water stress on yield and yield components of drip irrigated maize

The data in table 6 show the effect of irrigation treatments on the yield of drip irrigated maize. Irrigation treatments did not have any significant effects on the biological yield of maize in the two seasons. The irrigation treatments affected significantly on the grain and straw yield in the first season, but did not have any significant effects on the second season. However, the grain yield of maize irrigated by $\mathrm{I}_{75}$ was higher by 5 and $10 \%$ in the first and second season, respectively, compared to $\mathrm{I}_{100}$. Increasing the irrigation level to $100 \%$ of water requirements caused a 20 and $6 \%$ increase in the straw yield in the first and second season, respectively, also it caused a $20 \%$ increase in the biological yield in the first season. The data of the current study indicated that water stress caused a slightly reduction in the straw and biological yield of maize, on the other hand it caused a slightly increase in the grain yield. These results are in agreement with those obtained Hammad and Ali (2014) who studied the effect of irrigation treatments (irrigation after the depletion of 50 and $80 \%$ of available soil water) and they found that increasing irrigation level increased the plant highest and shoot dry mater biomass by 31 and $73 \%$, respectively. Increasing the plant highest and dry mater biomass will increase the straw yield rather than grain yield. Our findings are in agreement with Zhang and Oweis (1999), Zhang et al. (1999) and Kanga et al. (2002).

Table 6. Grain (GY) straw (SY), and biological yield (BY) $\left(\mathrm{kg} \mathrm{ha}^{-1}\right)$ of maize as affected by irrigation rates.

\begin{tabular}{|c|c|c|c|c|c|c|}
\hline \multirow{2}{*}{$\begin{array}{c}\text { Irrigation } \\
\text { level }\end{array}$} & \multicolumn{3}{|c|}{$\mathbf{2 0 1 4}$} & \multicolumn{3}{c|}{$\mathbf{2 0 1 5}$} \\
\cline { 2 - 7 } & $\mathbf{G Y}$ & $\mathbf{S Y}$ & $\mathbf{B Y}$ & $\mathbf{G Y}$ & $\mathbf{S Y}$ & $\mathbf{B Y}$ \\
\hline $\mathbf{I}_{\mathbf{1 0 0}}$ & $8004^{\mathrm{a}}$ & $25108^{\mathrm{a}}$ & $33112^{\mathrm{a}}$ & $6769^{\mathrm{a}}$ & $23127^{\mathrm{a}}$ & $29896^{\mathrm{a}}$ \\
\hline $\mathbf{I}_{\mathbf{7 5}}$ & $8411^{\mathrm{a}}$ & $21366^{\mathrm{b}}$ & $27444^{\mathrm{b}}$ & $7453^{\mathrm{a}}$ & $21740^{\mathrm{a}}$ & $29193^{\mathrm{a}}$ \\
\hline
\end{tabular}

Means denoted by the same letter indicate no significant difference according to Duncan's test at $P<0.05$ 


\section{Effect of water stress on water use efficiency of drip irrigated maize}

The data in Fig. 4 and 5 show the water use efficiency (WUE) and irrigation water use efficiency (IWUE) of maize as affected by the different irrigation levels. Irrigation treatments affected significantly in the WUE and IWUE in the two growth seasons. WUE was higher by 41 and $56 \%$ in the first and second season, respectively, in the case of $\mathrm{I}_{75}$ compared to $\mathrm{I}_{100}$. IWUE of the wheat plants irrigated by $\mathrm{I}_{75}$ was higher by 41 and $40 \%$ in the first and second season, respectively, compared to $\mathrm{I}_{100}$. Under water stress water was used efficiently more than normal irrigation. The higher values of water use efficiency observed under water stress treatment as compared to normal irrigation was mainly due to less water applied for these treatments and the high obtained grain yield. These results are in agreement with those repents by Howell et al. (1995). Zhang et al. (2004) reported that it is feasible to reduce irrigation amount in a certain growing stage of maize to maximize the irrigation water productivity. Deficit irrigation is one of the most important ways of maximizing water use efficiency (Bekele and Tilahun, 2007).

\section{Conclusions}

A field study for two years was conducted to evaluate the response of drip irrigated maize to water stress. Increasing the irrigation water to $100 \%$ increased the plant growth, nutrients uptake, and biological yield of maize. The grain yield of maize irrigated by $75 \%$ of water requirements was higher by $5-10 \%$ than that received $100 \%$ of water requirements. Irrigation the drip irrigated maize by $100 \%$ of water requirements increased the vegetative growth rather and this increased the straw and lead to a slightly reduction in the grain yield. Under drip irrigation system maize can be irrigated by only $75 \%$ of water requirements without any loss in the grain yield. 


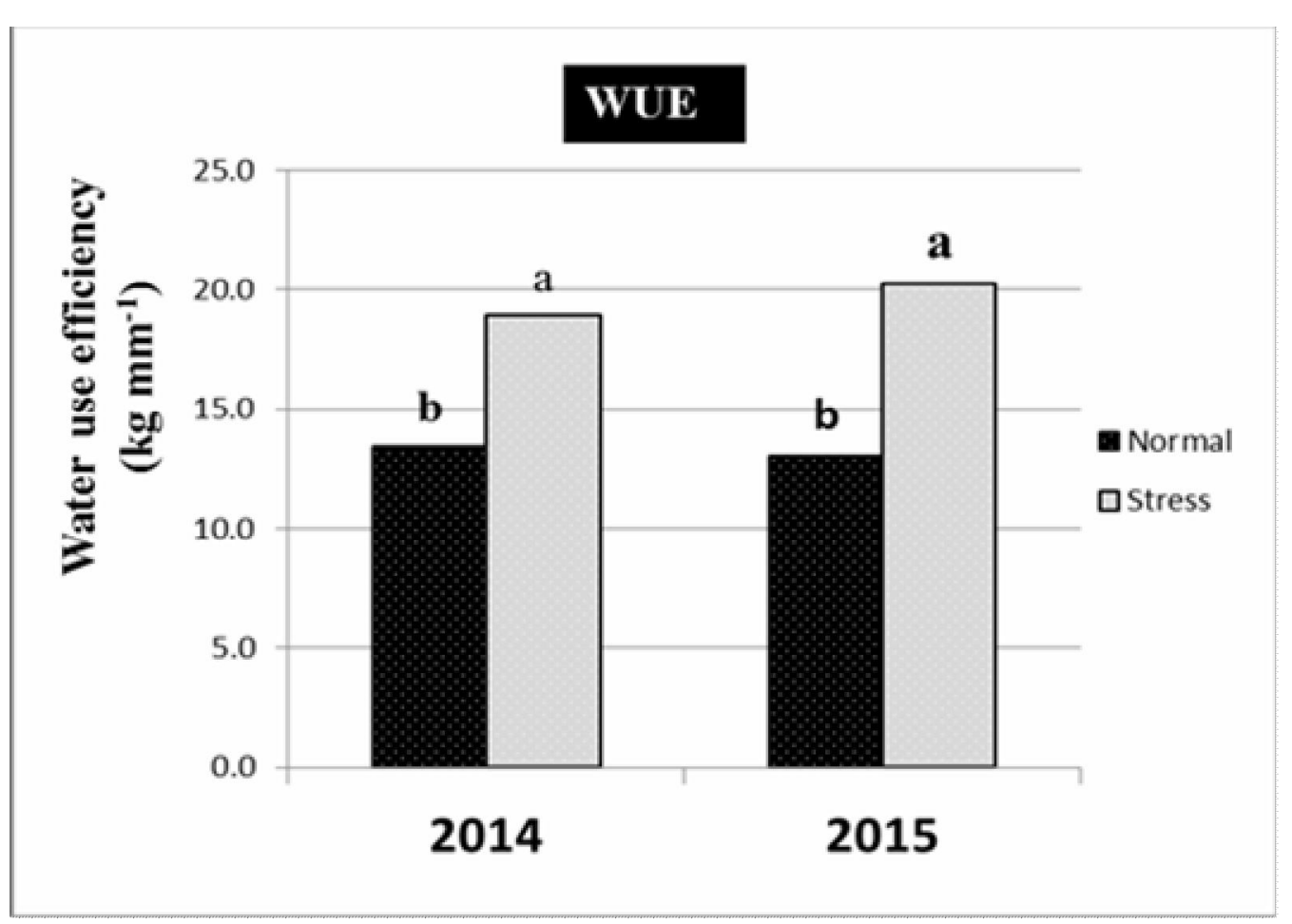

Fig 4. Water use efficiency (WUE) ( $\mathrm{kg}$ grain yield $\mathrm{mm}^{-1}$ of water) of maize as affected by irrigation rates.

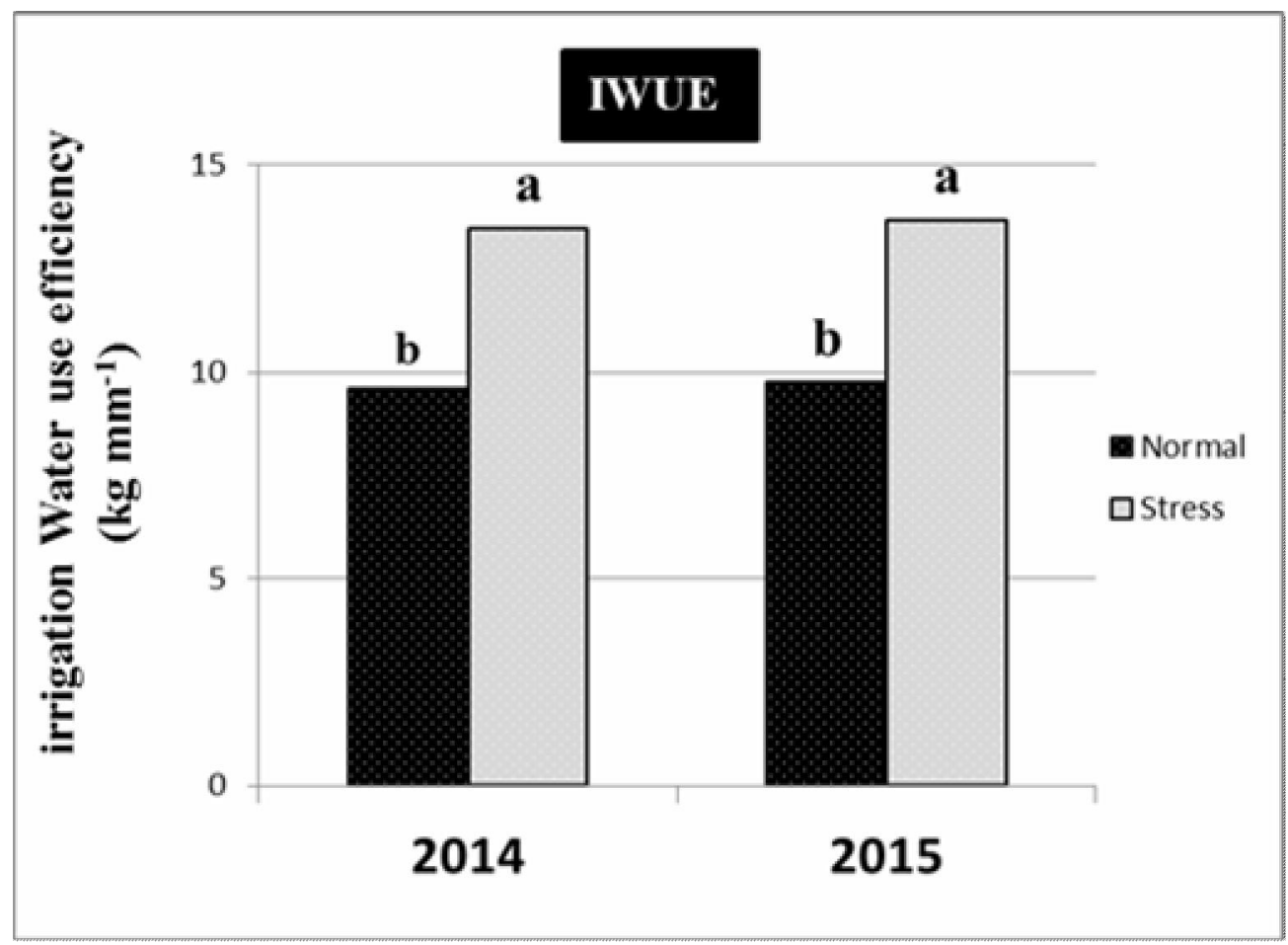

Fig 5. Irrigation Water use efficiency (IWUE) ( $\mathrm{kg}$ grain yield $\mathrm{mm}^{-1}$ of water) of maize as affected by irrigation rates. 


\section{References}

Abd El-Hafez, S. A.; A. A. El-Sabbagh; A. Z. El-Bably and E. I. AboAhmed. 2001. Response of maize crop to drip irrigation in clay soils. Alex. J. Agric. Res. Egypt, 46(2): 153-159.

Abd El-Hafez, S. A.; H. A. Meshref ; K. H. El-Hamdi and G. S. I. ElAtawy. 2008. Effect of irrigation, nitrogen and organic fertilization on soil water relationships of Zea maize crop. J. Agric. Sci. Mansoura Univ., 33 (7): 5409-5418.

Abd El-Rahman, G., 2009. Water Use Efficiency of Wheat under Drip Irrigation Systems at Al-Maghara Area, North Sinai, Egypt. American-Eurasian J. Agric. \& Environ. Sci., 5 (5): 664-670.

Abdel-Aziz, A. and U. S. El-Bialy. 2004. Response of maize plant to soil moisture stress and foliar spray with potassium. J. Agric. Sci. Mansoura Univ., Egypt, 29(6): 3599-3619.

Abdel-Maksoud, H. H.; M. R. K. Ashry and K. M. R. Youssef 2008.Maize yield and water relations under different irrigation and plant density treatments. J. Agric. Sci. Mansoura Univ., 33 (5): 3881- 3893.

Allen, G. R.; L. S. Pereira; D. Raes and M. Smith.1998. Crop evapotranspiration guidelines for computing cropwater requirements. Irrigation anddrainage paper 56, FAO, Rome, Italy.

Bekele, S. and K. Tilahun. 2007. Regulated deficit irrigation scheduling of onion in a semi-arid region of Ethiopia. Agric. Water Manage., 98(1-2): 148-152.

Bolaoos, J.; G. O. Edmeades and L. Martinetz. 1993. Eight cycles of selection for drought tolerance in lowland tropical maize. III. Response in drought adaptive physiological and morphological traits.
Field Crops Res.31: 269-86.

Burt, R. 2004.Soil survey laboratory methods manual. Soil Survey Investigations Report No. 42, Version 4.0, Natural Resources Conservation Service, United States Department of Agriculture.

Eissa, M. A.; M. Nafady; H. Ragheb and K. Attia. 2013. Effect of Soil Moisture and Forms of Phosphorus Fertilizers on Corn Production under Sandy Calcareous Soil. World Applied Sciences Journal 26 (4): 540-547 ISSN 1818-4952.

El-Nagar, G. R., 2003.Integrating of mineral and Bio-fixed nitrogen fertilization in maize production under different irrigation regimes.Assiut J. Agric. sci., 34 (5): $53-76$.

Erdem, T.; L. Delibas and A. H. Orta. 2001. Water-use characteristics of sunflower (Helianthus annuus L.) under deficit irrigation. Pakistan Journal of Biological Sciences 4: 766-769.

Gaber, A. M., 2000. Water consumptive, water use efficiency and production of some wheat varieties. Egypt, J. soil Sci. 40(4): 545-556.

Galbiatti, J. A.; M. J. Borges; L. F. Bueno; A. Garcia and R. D. Vieira. 2004. Effect of different irrigation periods in the development, yield and seedling quality in the maize (Zea mays L.) crop. Engenharia Agricola 24(2): 301-308.

Hammad, S. A. R. and O. A. M. Ali. 2014. Physiological and biochemical studies on drought tolerance of wheat plants by application of amino acids and yeast extract. Ann. Agric. Sci., 59(1):133-145.

Howell, T. A.; A. Yazar; A. D. Schneider; D. A. Dusek and K. S. Copeland. 1995. Yield and water use efficiency of maize in response to LEPA irrigation. Trans. ASAE 38: 1737-1747. 
Ibrahim, S. A and H. Kandil. 2007. Growth, Yield and Chemical Constituents of corn (Zea maize L.) as affected by nitrogen and phosphors fertilization under different irrigation intervals. Journal of Applied Sciences Research, 3(10): 1112 1120.

Ibrahim, S. M., 1999. Wheat cultivation under limited irrigation and high water table conditions. Egypt. J. Soil Sci. 39 (3): 361-372.

Jackson, M. L., 1973.Soil Chemical Analysis.Prentice-Hall, Inc. Englewood Cliffs, N.J. New Delhi, India.

Jones, R. A., and C. O. Qualset. 1984. Breeding crops for environmental stress tolerance. In: Application of Genetic Engineering to Crop Improvement, eds. G. B. Collins, and J. G. Petolino,: 305-340. Dordrecht, the Netherlands: MartinusNijhoff/Dr. W. Junk Puublishers.

Kanga, S.; L. U. Zhang; L. Yinli; H. Xiaotao; C. Huanjieand G. Binjie 2002. Effects of limited irrigation on yield and water use efficiency of winter wheat in the Loess Plateau of China. Agricultural Water Management55(3): 203-216.

Kara, T. and C. Biber. 2008. Irrigation frequencies and corn (Zea mays L.) yield relation in Northern Turkey. Pak. J. Sci., 11(1): 123-126.

Konopka, B.; L. Pages and C. Doussan 2009. Soil compaction modifies characteristics of seminal maize roots. Plant, Soil and Environment, 55: $1-10$.

Larcher, W., 2003.Physiological Plant Ecology. Berlin: Springer-Verlag.

Mansouri-Far, C. S. A.; M. M. Sanavy and S. F. Saberali. 2010. Maize yield response to deficit irrigation during low sensitive growth stages and nitrogen rate under semi-arid climatic conditions. Agricultural Water Management 97(1): 12-22.

Megyes, A.; J. Nagy; T. Rátonyi and L. Huzsvai. 2005. Irrigation of maize (Zea mays L.) in relation to fertilization in a long-term field experiment. ActaAgron. hungaria53(1): 41-46.

Meleha, M. I. 2006.Water management of maize crop on North Delta. J. Agric. Sci. Mansoura Univ., 31(2): 1185-1199.

MSTAT 1987.A microcomputer program for the design, management and analysis of agronomic research experiments. Michigan State University

Ogretir, K., 1993. The water-yield relationships of corn in Eskişehir conditions.PhD thesis, Irrigation and Agricultural Structures, Graduate School of Natural and Applied Sciences.Cukurova University, Adana.

Olsen, S.R., C. V. Cole, F. S. Watanabe and L.A. Dean. 1954. Estimation of available phosphorus in soils by extraction with sodium bicarbonate. United States Department of Agriculture Circular 939, Washington, DC, $19 \mathrm{p}$.

Omran, W. M., 2005.Maize yield response to available soil moisture.Monofiya J. Agric. Res. 30 (4): 1257-1268.

Othman-Sanaa A.; A. M. M. Shehata and I. M. El-Naggar 2005. Effect of rice straw compost and $\mathrm{N}$ fertilization on maize production and some soil physical properties. Minufiya J. Agric. Res., 30 (6): 1853-1863.

Page, A. L.; R. H. Miller and D. R. Keeney. 1982. Methods of Soil Analysis. Part 2: Chemical and microbiological properties. $2^{\text {nd }}$ ed. Amer. Soc. Agron.Inc. Soil Sci. Soc. Of Am., Madison, Wisconsin, USA. 
Parkinson, J. A. and S. E. Allen. 1975. A Wet Oxidation Procedure Suitable for the Determination of Nitrogen and Mineral Nutrients in Biological Materials. Communications in Soil Science and Plant Analysis, 6: $1-11$.

Pascale S. D.; R. Paradiso and G. Barbieri. 2001. Recovery of physiological parameters in Gladiolus under water stress. ColtureProtette. 30 (7):65- 69.

Rhoades, J. D. 1982. Soluble salts. P.167-180 In A.L. Page, R.H. Miller and D.R. Keeney. Methods of soil analysis, part 2. Chemical and microbiological properties $2 \mathrm{nd}$ edition. Soil Sci. Soc. Am. Inc., Madison, WI, USA

Rhoads, F. M. and J. M. Bennett. 1990. Maize. In: B. A. Stewart, and D.R. Nielsen, eds. Irrigation of Agricultural Crops: 569-596.

Silber, A.; G. Xu and R. Wallach. 2003. High irrigation frequency: the effect on plant growth and on uptake of water and nutrients. Acta Hort. (ISHS) 627:89-96.

Soil Survey Staff, 2014. Keys to soil taxonomy, $12^{\text {th }}$ ed USDA, Natural Resources, Conservation Services, Washington, D.C., USA.

Stone, P. J.; D. R. Wilson; J. B. Reid and G. N. Gillespie. 2001. Water deficit effects on sweet maize: I. Water use, radiation use efficiency, growth, and yield. Aust. J. Agric. Res. 52: 103-113.
Viswanatha, G. B.; $\quad$ B. K. Ramachandrappa and H. V. Nanjappa. 2002. Soil-plant water status and yield of sweet corn (Zea mays L. cv. Saccharata) as influenced by drip irrigation and planting methods. Agric. Water Manage.55: 8591.

Wang, F. Z.; Q. B. Wang; S. Y. Kwon; S. S. Kwak and W. A. Su. 2005. Enhanced drought tolerance of transgenic rice plants expressing a pea manganese superoxide dismutase, J. Plant Physiol. 162: 465472.

Zhang, H. and T. Oweis. 1999. Wateryield relations and optimal irrigation scheduling of wheat in the Mediterranean region Agric. Water Manage., 38: 195-211

Zhang, H.; X. Wang; M. You and C. Liu. 1999. Water-yield relations and water use efficiency of winter wheat in the north China plain Irrigation Sci., 19: 37-45

Zhang, Y.; E. Kendy; Y. Qiang; L. Changming; S. Yanjun and S. Hongyong. 2004. Effect of soil water deficit on evapotranspiration, crop yield, and water use efficiency in the north China plain. Agric. Water Mgmt. 64(1): 107122.

Zhu, J. K., 2002. Salt and drought stress signal transduction in plants, Annu. Rev. Plant Biol. 53: 247273. 
تأثير الاجهاد المائي علي الذرة الثامية النامية تحت نظام الري بالتنقيط

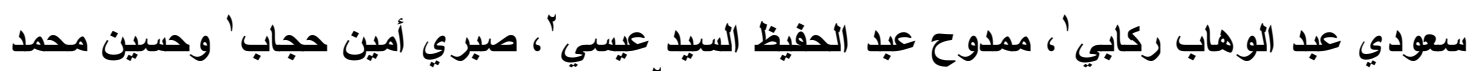

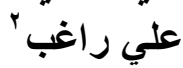

$$
\begin{aligned}
& \text { ' قسم الأراضي والمياه - كلية الزراعة - جامعة الأزهر - أسيوط - مصر - مصر }
\end{aligned}
$$

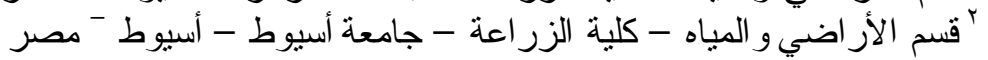

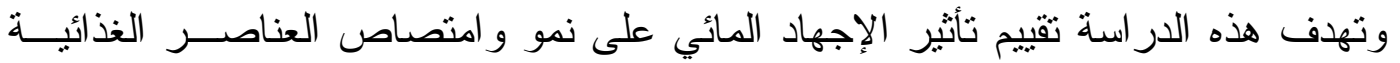

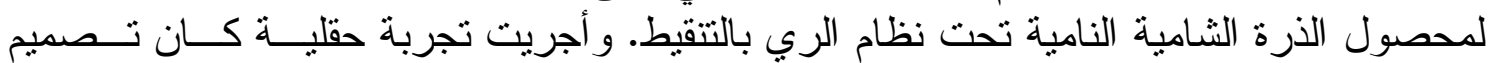

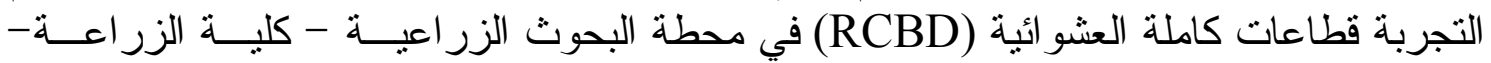

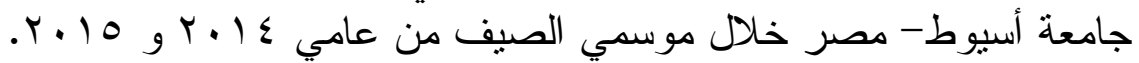

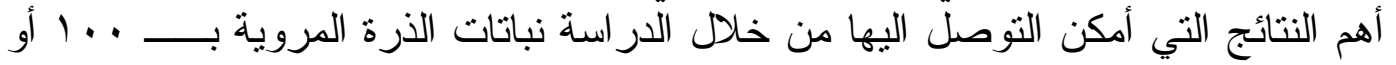

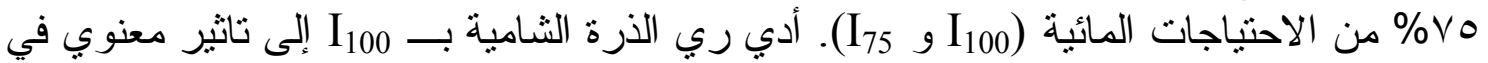

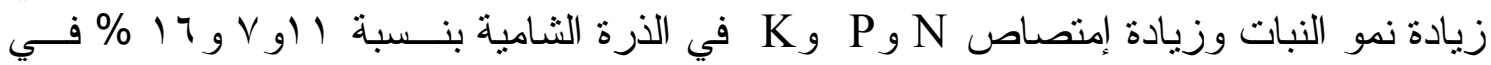

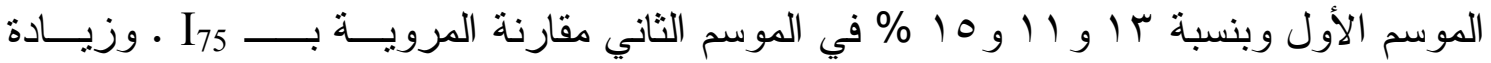

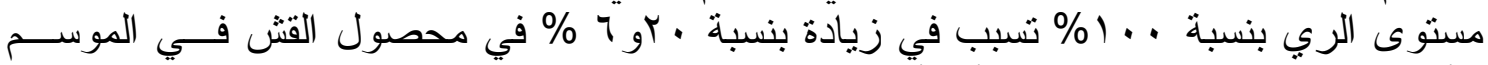

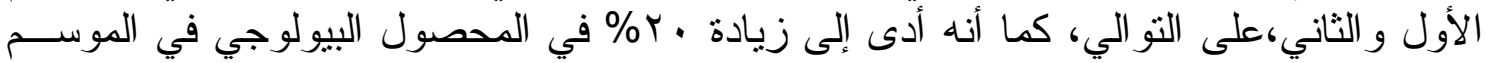

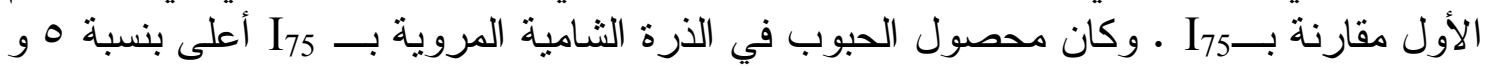

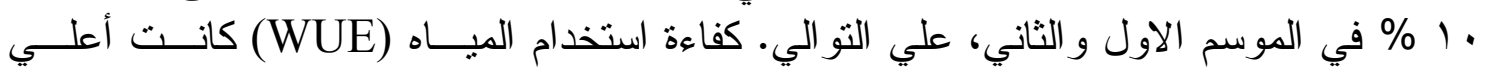

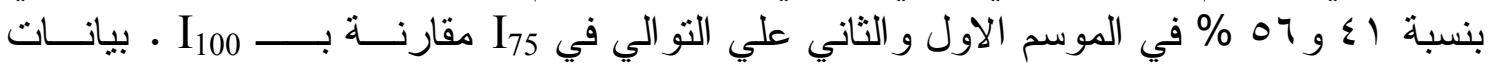

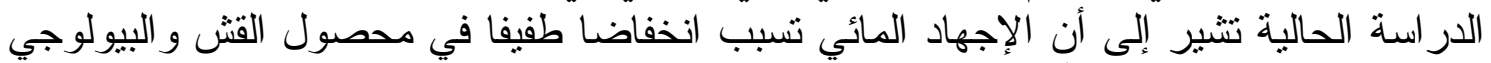

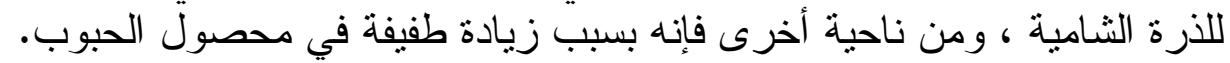

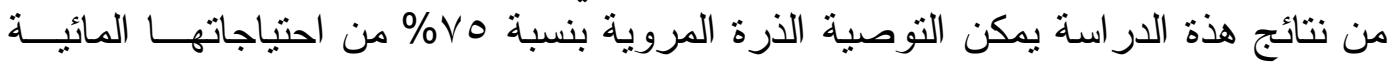

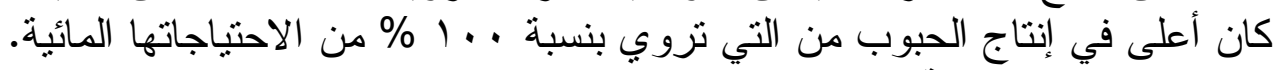

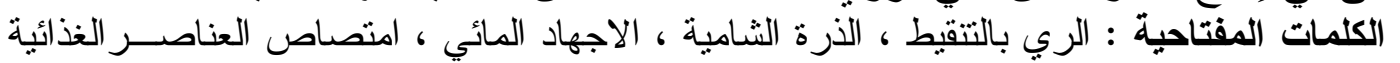
، كفاءة استخدام المياه ، المحصول. كل الري بل 